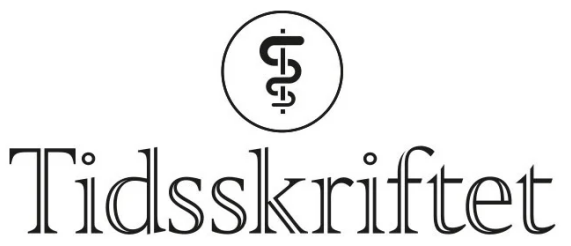

DEN NORSKE LEGEFORENING

\title{
Luft i cerebrale venesinuser
}

MEDISINEN I BILDER

\section{ANETTE MIDTGARD}

anette.midtgard@helse-mr.no

Radiologisk avdeling

Ålesund sjukehus

Anette Midtgard er spesialist i radiologi.

Forfatteren har fylt ut ICMJE-skjemaet og oppgir ingen interessekonflikter.

\section{KRISTOFFER ØKSENVÅG SAND}

Medisinsk avdeling

Ålesund sjukehus

og

Institutt for helsevitenskap i Ålesund

NTNU

Kristoffer $\emptyset$ ksenvåg Sand er ph.d. og lege i spesialisering i blodsykdommer. Forfatteren har fylt ut ICMJE-skjemaet og oppgir ingen interessekonflikter.

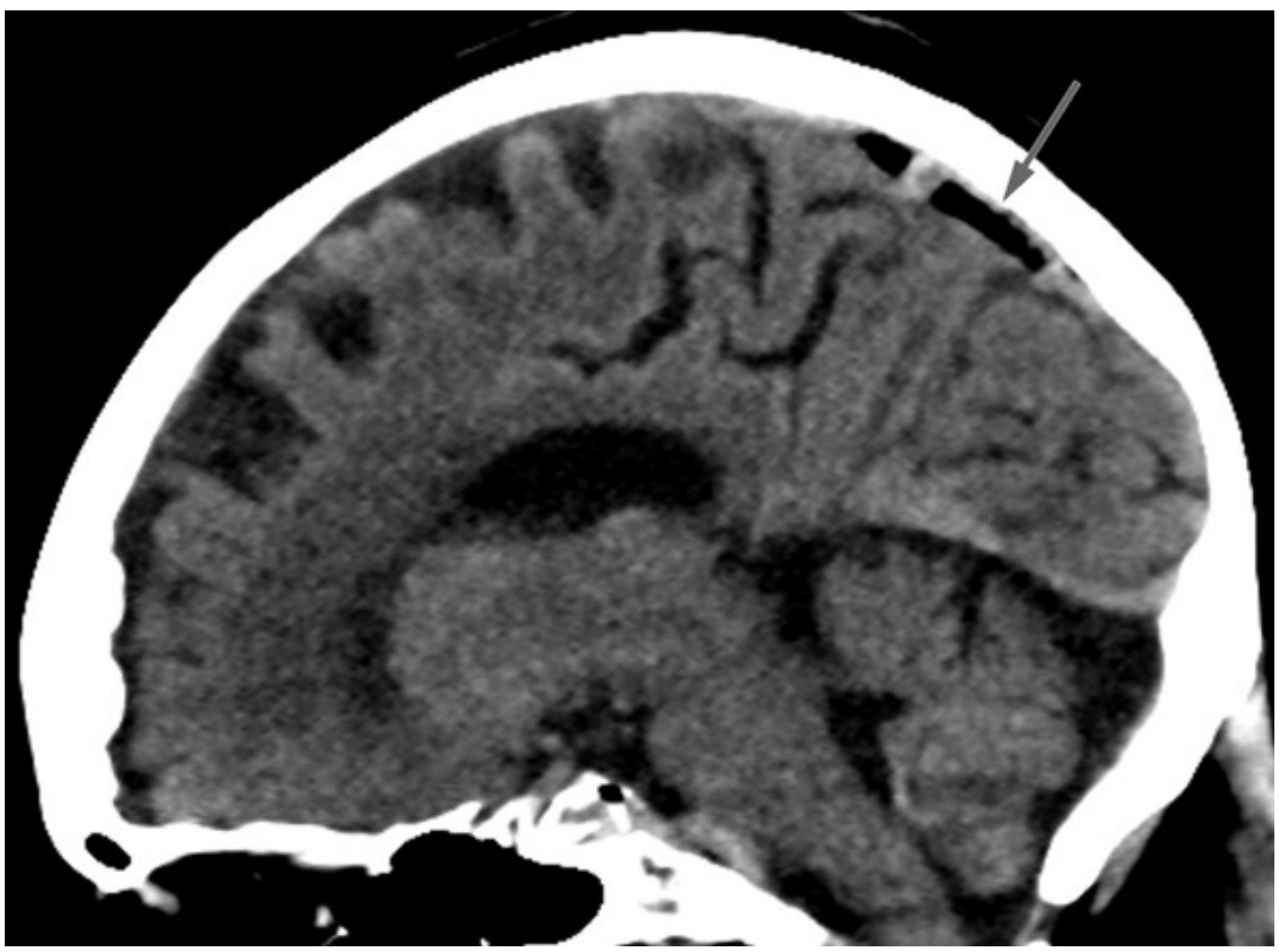


Bildet viser luft i sinus sagittalis superior, et tilfeldig funn hos en kvinne i 8o-årene undersøkt med CT caput ett døgn etter fall i hjemmet med hodetraume og forbigående bevissthetstap. CT viste ingen tegn til intrakranial blødning eller skjelettskade, men det var luft i cerebrale venesinuser, mest i sinus sagittalis superior, mindre luftbobler i sinus transversus bilateralt, høyre sinus sigmoideus, sinus cavernosus og i en vene kranialt i venstre orbita. Grunnet rask atrieflimmer hadde pasienten før CT fått anlagt perifert venekateter på høyre underarm med injeksjon av to doser med $5 \mathrm{mg}$ metoprolol. Pasienten hadde ingen symptomer som kunne tilskrives cerebral venøs luftembolisme.

Cerebral luftembolisme forekommer sjelden, er potensielt dødelig og kan presentere seg med uspesifikk encefalopati eller fokalnevrologiske utfall $(\underline{1}, \underline{2})$. Mistenkt årsak er ofte iatrogen prosedyre som manipulasjon av sentralt venekateter. Arterielle cerebrale luftemboluser er antatt hyppigere og relateres til en høyre-venstre-shunt, mens retrograd vandring av luftbobler fra systemvenøs sirkulasjon gjennom halsvener kan gi venøse cerebrale luftemboluser $(\mathbf{1}, 3)$.

Foreslått behandling er Trendelenburgs leie for å lede luften bort fra hodet, samt 100 \% oksygen for raskere reabsorpsjon av gassbobler $(\underline{2}, 3)$. Hyperbar oksygenbehandling vurderes ved alvorlige tilfeller (1-3). Det er usikkert hvorvidt asymptomatiske pasienter bør behandles. Vår pasient fikk 100 \% oksygen, men grunnet hjertesvikt ble hun ikke lagt i Trendelenburgs leie. Kontroll CT caput 13 timer etter første undersøkelse viste avtagende mengder luft. Supplerende CT cervikalcolumna/thorax var uten tegn til traumatisk skade som kunne forklare luftembolusene. Det må her mistenkes perifert venekateter som kilde, selv om traumatisk årsak ikke kan utelukkes. Pasienten hadde ikke vært utsatt for kirurgi, andre prosedyrer eller barotraume. Det ble ikke funnet avvik fra prosedyre ved gjennomgang av venekateteranleggelsen.

Pasienten har gitt samtykke til at artikkelen blir publisert.

Artikkelen er fagfellevurdert.

\section{LITTERATUR}

1. Heckmann JG, Lang CJ, Kindler K et al. Neurologic manifestations of cerebral air embolism as a complication of central venous catheterization. Crit Care Med 2000; 28: 1621-5. [PubMed][CrossRef]

2. Carneiro AC, Diaz P, Vieira M et al. Cerebral venous air embolism: A rare phenomenon. Eur J Case Rep Intern Med 2019; 6: 001011. [PubMed][CrossRef]

3. Schlimp CJ, Bothma PA, Brodbeck AE. Cerebral venous air embolism: what is it and do we know how to deal with it properly? JAMA Neurol 2014; 71: 243. [PubMed][CrossRef]

Publisert: 22. februar 2021. Tidsskr Nor Legeforen. DOI: 10.4045/tidsskr.20.0727

Mottatt 11.9.2020, første revisjon innsendt 12.11.2020, godkjent 9.12.2020.

(C) Tidsskrift for Den norske legeforening 2023. Lastet ned fra tidsskriftet.no 26. april 2023. 